\title{
Increasing the Brand Awareness of PT. Erindo Mandiri's Products through a Website
}

\author{
Jocelyn Clarisa Liando \\ English Department, Faculty of Languages and Literature, Petra Christian University, Siwalankerto 121-131, \\ Surabaya 60236, INDONESIA \\ Email:jocelynliando@gmail.com
}

\begin{abstract}
A website is important because it would increase the brand awareness of a product or service for brand awareness is closely associated with promotional tool. The goal here is to promote and introduce the product or service of a business to the public. PT. Erindo Mandiri was established in 1990 as a manufacturer of mineral water. The main product of the company is Aquase mineral water that have different packaging - cups, bottles, and gallons. The main problem the company is facing is the low brand awareness of their products. The problems make only few people know about the products. This problem led PT. Erindo Mandiri to have a lowincome rates problem. This inability is caused by the lack of appropriate tool used by the salesperson to explain and promote the products to agents and retailers. Therefore, the solution to PT. Erindo Mandiri is to improve or change the current website. This website can help the marketing staff to promote the company's product more effectively to agents and retailers. Then, they will be attracted to buy our products and do partnership with the company.
\end{abstract}

Keywords: brand awareness, promotional tools, company website.

\section{INTRODUCTION}

PT. Erindo Mandiri was established in 1990 as a manufacturer of mineral water. The production point is located in Jl. Dhamar Wulan 02 Desa Gambiran, Prigen, Pasuruan. PT. Erindo Mandiri currently stations its marketing head office in Surabaya and owns 7 distribution and service points in East Java for example in Surabaya, Malang, Jember, Kediri, Madiun, Sidoarjo, and Gresik. Meanwhile I did my internship in one of the office located in Jl. Arief Rachman Hakim no 139, Surabaya. The main product of the company is Aquase mineral water that varied in different packaging of cup, bottle, and gallon. It is also implements the quality management system of ISO 90001:2000. PT. Erindo Mandiri serves its product for the domestic market for $95 \%$ while its $5 \%$ for export. Their target market includes distributors from Singapore, Dili, and Australia, while their local target market aims for all over Indonesia.

Within three months of me doing the internship in PT. Erindo Mandiri, I have found a problem concerning the company. The main problem the company is facing is the low brand awareness of their products. The problems make only few people know about the products, Aquase. Most of them do not know PT. Erindo Mandiri, the products, and the uniqueness and strengths. This problem led PT. Erindo Mandiri to have a low-income rates problem. This inability is caused by the lack of appropriate tool used by the salesperson to explain and promote the products to agents and retailers. The most effective promotional tool in this era is the digital one such as website so that people can easily access rather than printed one such as brochure or booklet (Cope, 2017) One of the examples is their website. That is why, with a website that lacks creativity, which does not have even one strength or USP highlighted, makes only few people know about PT. Erindo Mandiri's product, most of them do not know PT. Erindo Mandiri, its product, and more importantly its uniqueness or strengths. I am afraid if the Marketing Department use either the ineffective website, the agents and retailers would not be interested in doing partnership with the company.

I decided to choose the ineffective website problem as my Business Communication Final Project. Due to the ineffectiveness of their current website, I will make a new website to overcome this obstacle. A resolution for this issue is important because without a proper website, the Marketing staff will have trouble in doing their most important job: promoting the business to the agents and retailers. To make sure the company is well - known in its industry, they will need a good website. 
Customers will want to know first about the business, its credibility, and its products. Thus, the new website can help the marketing staff to promote the company including USPs, products more effectively to new customers. The website will not become an obstacle but instead a useful tool to attract more customers for the company. There are some theories that I used to make this project. First, the definition of promotion, based on Semenik (2002, p.7), promotion is "the communication process in the marketing that is used to create a favorable predisposition toward a brand of product or service, an idea, or even a person. According to Anne Pilon (2018, 30 Tips for building your first website business, there are 5 important tips to be followed in order to successfully designing a good company website that will attract more customers.

1. State the purpose clearly and quickly.

2. Develop page hierarchy.

3. Set up easy contact and include a contact form.

4. Keep design elements simple.

5. Add valuable images.

\section{METHODOLOGY}

To execute the Business Communication Final Project, there are sets of procedures that have to be completed before, during, and after doing the project. The following are the procedures that were completed in making the website for PT. Erindo Mandiri. The first one is to get an approval from the board of examiners. Therefore, there were some steps that I did to get their approval. First, I started to write a proposal of my BCFP. In the BCFP proposal, I mentioned the problems of PT. Erindo Mandiri based on the experience I got during the internship. PT. Erindo Mandiri has got ineffective tool to promote the products to agents and retailers that results in low brand awareness. There after that, I chose this problem, I explained the best solution for PT. Erindo Mandiri to solve their problem. I explained the reason why I choose website to solve the company's problem. Next, I also explained the benefits that the company would get from the website. In the second chapter of my BCFP proposal, I put the principles that I used in designing my website. After all those are done, I submit the proposal.

The next step after I submitted my proposal, I started my proposal defense. On the proposal defense, I presented my BCFP proposal. I tried to convince the examiner that the problem I chose for my BCFP is important that needs to be solved as soon as possible, and the project that I chose is the best solution to solve the company's problem. Then after I finished with my presentation, the examiners asked me some questions and gave me some feedbacks. They give me feedback to be very careful in the grammar while writing the report and want me to immediately to do the project that focus to highlight the USP. Lastly, I got the approval to do the project with some revisions on the BCFP proposal. After I got the acceptance from the board of examiners, I need to get the approval from the company. Therefore, the first thing that I did was discuss it with my Marketing Manager, Mr. Agus. I started talking and explaining about my final project. Then after that, I started talking about the product that I would make it a website for PT. Erindo Mandiri. Then, he asked me to make company proposal and discuss it with the owner, Mr. Sunario. I started to make a company proposal. I explained the background of the problems and why I wanted to make a website. He asked me to explain further about the concept of the website, the USPs of the products. Then he gave me advices for the content that it should be very attractive by adding moving animation and events. Furthermore, he gave me his partner phone number who is working at JCK Enterprise to help me with the website. Then the second step, I started to make a letter of agreement or contract to avoid miscommunication between us. After finish making the contract, I submit the contract and waiting to be called. On the other hand, I also contact the JCK team about their fee. I got the information that the company has already paid half price for the down payment for the website. Therefore, after he agreed with my concept and idea, he asked me to work as soon as possible. Finally, my proposal got accepted and signed. The tool for my Business Communication Final Project is a website. There are 5 items for my content, Home, Why Aquase, Products, Gallery, and Special Offer Now. The USP of PT. Erindo Mandiri's product are the mineral water is healthy because it comes from higher spring water and it is processed hygienically will be highlighted in the forms of words and pictures. The website is going to be in both Indonesian and English languages because the customers are mostly not local customers but also international customers for the future needs. The website is aimed new customers. By having 
this website, they can know the uniqueness and strength of the products of PT. Erindo Mandiri and interested to do a partnership with the company. In the making of the Business Communication Tool for PT. Erindo Mandiri, there were some procedures I have accomplished. Firstly, I gathered all necessary data including information and photos regarding all the company's information from the company profile booklet, interviewing the staffs, conducting a survey to people in Surabaya, and doing company visit to see the production process at Prigen. I arranged all the information and categorize them into the two main USPs that I got: the natural source that comes from higher spring water from Mount Penangungan and the hygienic production process. I got the USP is based on my interview with workers while visiting the company at Prigen. They all agreed that this water is healthy and fresh because of the source and hygienic process, so that they gave me feedback to focus on highlighting this point in the website. The next step is to consult the table content to the managers and owner. I will take the photos of several things such as products, production process, and certifications. Some of them I will do it at the marketing office in Surabaya and for the production process I will visit the company in Prigen. The owner told me to combine both infographic and real pictures for the process so that customers will get attracted and easily understanding the process. After the revised version of the content was submitted and approved, the photo session was scheduled at conducted. My manager suggests me to conduct the photoshoot at the marketing office and places that are using Aquase so that we can promote the places as well. Following the photo session is the copywriting. I got many feedbacks from my advisor to focus on the grammar. Next, I arranged the content including the pictures and text into a complete company profile and consulted them to my advisor before handling them to PT. Erindo Mandiri. My advisor agreed and do some revision with the "special offer now" page by adding types of request to make it easier for customer to state their request. The last step to do is to present the website to PT. Erindo Mandiri. Luckily, when I submit the website, the owner and managers were amazed with the result. They had checked all the necessary data are all correct. Finally, I could publish in the internet.

\section{FINDINGS AND DISCUSSION}

The rational of the product will be elaborated in an orderly manner. The justification of every decision and selection of the feature will be explained further as follows:

The first feature that I used is "Home". This feature as the most important one is placed in the first page or main page of the website in order to grab the visitor's attention to stay and see the other features in the website. In this "Home" page, I put PT. Erindo Mandiri's main product, Aquase, in the middle of the page to keep aware of this brand. Then, I use moving animation from the Mount Penanggungan to the factory to highlight that this company product is healthy since it is less contaminated unlike other brands. Besides the moving animation, I put a tagline "healthy, but not pricey" to inform the visitors that usually to stay healthy is very expensive, we need to drink a lot of vitamins, have a routine checkup, etc. However, by drinking this mineral water regularly it can make them stay healthy. I also added two short paragraphs about an overview of the company such as their milestone, address, and USPs. Next, I also put latest events that the company held within this year. Up until now, we have three events with photos as details. On the footer, there are certifications and the company's contact number. It is very important so that the visitors always keep in mind the product is certified and they could possibly contact directly by seeing the number in every page. Thus, by reading the main page, they will have a good image to the products of PT. Erindo Mandiri and the company itself.

The second feature that I use in the website is "Why Aquase". This feature contains the unique selling point (USP) of the products that is highlighted in blue font color. First, the water comes from a higher spring water and the hygienic production process. From the first USP, it is clearly mentioned that the water is sourced from a higher spring water so that the quality and freshness is guaranteed. Not only mentioning the source, I put the hygienic production process as the second USP to give more detail information about how the company maintained the water quality until it will be consumed by the customers. It is clearly stated with a strong benefit in every stage. I combined both infographic and real pictures taken from the company at Prigen to make a very effective process and attract the visitor's attention. This feature is also important to give a potential customer an information about PT. Erindo Mandiri's product and why they should choose the product rather than other bran 
The third feature is "Products". In here, I put the products of PT. Erindo Mandiri which is Aquase that come in various sizes. In here, there are 6 sizes being offered by the company such as $120 \mathrm{ml}, 240 \mathrm{ml}, 330 \mathrm{ml}, 600 \mathrm{ml}, 1.5 \mathrm{~L}$, and $19 \mathrm{~L}$. There are also some photos with explanation about the suitable consumption place for each size. This page will give the visitors a product knowledge about the company's product, so they will more likely to purchase the product.

The fourth feature in this website is "Events". This feature contains all events that being held by the company. Up until now, we have conduct three events in Surabaya. In each event, there will be pictures taken during the event, name of the event, and the date it was held. Thus, the visitors will acknowledge PT. Erindo Mandiri's existence in corporate social responsibility events, health events, sport events, and more. As there will be more events in the future, this page will be update continuously so that visitors will keep updated. This page is also important so that visitors have a good brand awareness to the company and the products by joining and holding many events.

The last feature is "Special Offer Now". I choose the feature's title Special Offer Now instead of Contact Us, because I would like to make the visitors especially agents and retailers attracted to buy the products or do partnership with the company just by reading the title of the feature. This feature contains a form that they need to fill in order to get their request such as special prices, partnerships for agents and retailers, sponsorship, and others. Besides, they need to fill their name, phone number, email, and the message so that the sales administrator could possibly contact them for the further discussion. The form is designed in a simple way to ensure customers can easily state their request or feedbacks. Besides, there is also google driving maps that allows the visitors to get an auto direction on their phone when they click on the maps in this feature.

\section{CONCLUSION}

For my Business Communication Final Project (BCFP), I decided to make a new website for PT. Erindo Mandiri, a mineral water company. The problem of PT. Erindo Mandiri is their low sales income caused by the salesperson inability to get the products into agents and retailers. Basically, this problem is started from their bad promotion tools PT. Erindo Mandiri used from 2010. Their website is out of date and very ordinary without highlighting any of their strength or uniqueness. Then, this problem led PT. Erindo Mandiri into a new problem which is a low-income rate. The company never takes a significant action to solve this problem. Therefore, in order to solve this problem, PT. Erindo Mandiri needs to fix their promotion tools as soon as possible. Up until now, PT. Erindo Mandiri only revised or improved their printed brochure while in this digital era, people rarely see the brochure of the company. Besides, the brochure is limited while website is unlimited. It can be reached by many people anywhere and anytime. A website can help the company to increase the sales better because website can reach a broader target market. There are five components in the website: Home, Why Aquase, Products, Events, and Special Offer now! These five features are important in the website, because it will help PT. Erindo Mandiri to introduce their product and to show their strength and uniqueness. First, in "Home" feature, it will be shown a moving animation from the source taken from Mount Penanggungan to the retailers and agents that this company's product is less contaminated because taken from the higher spring water. Besides, is the latest event that we held to make people aware about our existence. It is very important to make the first page interesting and give the visitors a strong message about the company. The second feature is "Why Aquase". In this feature, there will be three points highlighted which are the source that is taken from the higher spring water, hygienic production process, and the certifications. This page is very important so that the customers know the reason why they should consume this mineral water instead of others. The third feature is "Products". Aquase is the main products of PT. Erindo Mandiri. Therefore, there are pictures of size of Aquase mineral water. There are six sizes of Aquase Mineral Water: $120 \mathrm{ml}, 240 \mathrm{ml}, 330 \mathrm{ml}, 600 \mathrm{ml}, 1.5 \mathrm{~L}$, and 19L. There is also a brief explanation about each size. The fourth feature is "Events". In this page, there will be a continuous update from the admin every time the company held an event. Within this year, we have already done three events in Surabaya. Not only mentioning the events, it will be given a lot of pictures during the event. The fifth feature is "Special Offer Now". In this feature, there are contact information about the company's phone number, email, and google map. Besides, there is also contact form so that after reading the website, they will be interested to do partnership with the company. They just need to fill name, email, phone number, and the message. After they complete the form, the administrator will 
directly contact them to discuss about the partnerships. I hope that PT. Erindo Mandiri can use the website effectively to increase their sales. They can continually update their content and promote their product or event more on this website. By keeping the website updated, it shows the professionality of the company itself. Since it will be uploaded online, so that every people can see and access through it, it will not the limit the number of potential customers. I hope that by using this website, PT. Erindo Mandiri can gain more customers not only from Indonesia, but abroad.

\section{REFERENCES}

Cope, E. (2017). why your website is your most important marketing tool. Retrieved December 1, 2018, from https://www.cope-salesandmarketing.com/website-important-marketing-tool/

Pilon, A. (n.d.). 2018. 30 Tips for Building Your First Business Website. Retrieved November 15, 2018, from https://smallbiztrends.com/2015/10/building-your-first-business-website.html Semenik, R. (2002). Promotion and Intergrated Marketing Communication. Canada: South Western Thomson Learning. 